\section{Nota sobre Myrian Veras Baptista}

Notes on Myrian Veras Baptista

\section{Michael Löwy}

Diretor de Pesquisas Emérito do Centre National de la Recherche Scientifique (CNRS)/Paris.

michael.lowy1@gmail.com

Tive a sorte de colaborar com Myrian durante vários anos. Supervisei seu pós-doutorado e pouco depois ela me convidou a dar um curso no Programa de Pós-Graduação em Serviço Social da PUC-SP. Foi ela quem me estimulou a fazer desse curso um livrinho que a Cortez Editora publicou com o título Ideologia e Ciências Sociais. E foi graças à Myrian que estabeleci uma relação estreita com as colegas do Serviço Social que dura até hoje. São muitas dívidas que tenho com ela... Myrian era não só uma grande professora e pesquisadora, mas também uma pessoa inspirada por um profundo compromisso social, uma profunda identificação com a causa dos explorados. Ela nos fará muita falta...

Recebido em 22/10/2015

Aprovado em 23/10/2015 